\title{
ANALISIS EFEKTIVITAS SISTEM PENGENDALIAN INTERNAL PAJAK BAHAN BAKAR KENDARAAN BERMOTOR DAN KONTRIBUSINYA TERHADAP PENDAPATAN ASLI DAERAH PROVINSI SULAWESI UTARA
}

\author{
Tondy Maranatha Rajagukguk ${ }^{1}$, Jantje J. Tinangon ${ }^{2}$, Heince R. N. Wokas ${ }^{3}$ \\ 1,2,3 Jurusan Akuntansi, Fakultas Ekonomi dan Bisnis, Universitas Sam Ratulangi, Jl. Kampus Bahu, Manado, \\ 95115, Indonesia \\ E-mail : m_tondy@yahoo.com
}

\begin{abstract}
Vehicle fuel tax is a type of local tax, which is a source of revenue to increases locallygenerated revenues. Vehicle fuel tax is managed by Regional Tax and Retribution Management Agency (RTRMA) of North Sulawesi, where each registered companies are compulsory levy, which is periodically required to report and deposit the proceeds of the sale of fuel to RTRMA. This research aims to know the effectiveness of the internal control system and the contribution of vehicle fuel tax to the locally-generated revenue of North Sulawesi. The method used in this research is descriptive qualitative. The results of the research show that the internal control system in the calculation process, collection and reporting of vehicle fuel tax has been worked well. In addition, the criteria for effectiveness and contribution based on the calculation of the average vehicle fuel tax revenue in 2013-2017, explained that the results of vehicle fuel tax were very effective and sufficiently contributed to the locallygenerated revenue of North Sulawesi.
\end{abstract}

Keywords: Internal Control System, Vehicle Fuel Tax

\section{PENDAHULUAN}

Pemerintah daerah menetapkan pajak bakar kendaraan bermotor sebagai sumber pendapatan daerah. Setiap penggunaan bahan bakar kendaraan bermotor akan dikenakan PBBKB. Pajak bahan bakar kendaraan bermotor bergantung pada konsumsi/penggunaanya, dimana semakin banyak pengguna maka akan semakin tinggi pula pendapatan daerah dari pajak bahan bakar kendaraan bermotor. Penggunaan bahan bakar kendaraan bermotor seperti bensin (premium, solar, pertamax, pertalite, bio solar, dexlite, pertamina dex, dan pertamax turbo) akan dikenakan pajak bahan bakar kendaraan bermotor. Peraturan Pemerintah Daerah Provinsi Sulawesi Utara Nomor 7 Tahun 2011 tentang Pajak Daerah menyatakan bahwa salah satu sumber pendapatan daerah dari pajak adalah pajak bahan bakar kendaraan bermotor, dikarenakan sebagian besar masyarakat di Provinsi Sulawesi Utara merupakan pengguna kendaraan bermotor, hal tersebut akan berdampak pada konsumsi bahan bakar minyak dan akan meningkatkan penerimaan pajak bahan bakar kendaraan bermotor.

Kepatuhan wajib pajak dalam membayarkan kewajiban perpajakannya merupakan suatu bentuk dukungan masyarakat kepada pemerintah daerah untuk meningkatkan penerimaan daerah. Namun, perusahaan-perusahaan bahan bakar yang terdaftar di Badan Pengelola Pajak dan Retribusi Daerah (BPPRD) Provinsi Sulawesi Utara merupakan wajib pungut. Dalam hal ini BPPRD berperan sebagai given yang setiap bulannya akan menerima penyetoran hasil penjualan bahan bakar kendaraan bermotor dari masing-masing perusahaan. Adapun perusahaan-perusahaan yang terdaftar sebagai wajib pungut di Provinsi Sulawesi Utara terdiri dari, PT. Pertamina, PT. AKR, PT. Patra Niaga, PT. Elnusa Petrofin, PT. Global Arta Borneo, PT. Petro Energy dan PT. Bangun Mitra Sejahtera Int. 


\section{TINJAUAN PUSTAKA}

Efektivitas. Bungkaes (2013:45) menyatakan bahwa efektivitas adalah hubungan antara output dan tujuan. Dalam artian efektivitas merupakan seberapa jauh tingkat output, kebijakan dan prosedur dari organisasi mencapai tujuan yang ditetapkan.

Ukuran Efektivitas. Tingkat efektivitas juga dapat diukur dengan membandingkan antara rencana yang telah ditentukan dengan hasil nyata yang telah diwujudkan. Namun, jika usaha atau hasil pekerjaan dan tindakan yang dilakukan tidak tepat sehingga menyebabkan tujuan tidak tercapai atau sasaran yang diharapkan, maka hal itu dikatakan tidak efektif.

Perhitungan Efektivitas. Perhitungan efektivitas dilakukan dengan cara membagi antara realisasi pajak bahan bakar kendaraan bermotor dengan target pajak bahan bakar kendaraan bermotor Provinsi Sulawesi Utara, kemudian dikali dengan 100\%. Berikut adalah rumus perhitungan efektivitas :

$$
\text { Efektivitas PBBKB }=\frac{\text { Realisasi PBBKB }}{\text { Target } \mathrm{PBBKB}} \times 100 \%
$$

Penilaian kinerja rasio kriteria efektivitas dapat dilihat pada tabel di bawah ini.

Tabel 1. Rasio Kriteria Efektivitas

\begin{tabular}{|c|c|}
\hline PERSENTASE & KRITERIA \\
\hline$>100 \%$ & Sangat Efektif \\
\hline $90-100 \%$ & Efektif \\
\hline $80-90 \%$ & Cukup Efektif \\
\hline $60-80 \%$ & Kurang Efektif \\
\hline$<60 \%$ & Tidak Efektif \\
\hline
\end{tabular}

Sumber: Supriadi $(2015: 45)$

Kontribusi. Kontribusi adalah besaran sumbangan yang diberikan atas sebuah kegiatan yang dilaksanakan. Analisis kontribusi pajak daerah adalah suatu analisis yang digunakan untuk mengetahui seberapa besar kontribusi yang dapat disumbangkan dari penerimaan pajak terhadap PAD, maka dibandingkan antara dibandingkan antara realisasi penerimaan pajak daerah terhadap pendapatan asli daerah. (Handoko, 2013). Berikut adalah rumus perhitungannya :

$$
\text { Kontribusi PBBKB }=\frac{\text { Realisasi PBBKB }}{\text { Realisasi PAD }} \times 100 \%
$$

Penilaian kinerja rasio kriteria kontribusi dapat dilihat pada tabel di bawah ini.

Tabel 2. Rasio Kriteria Kontribusi

\begin{tabular}{ll}
\hline \multicolumn{1}{c}{ PERSENTASE } & \multicolumn{1}{c}{ KRITERIA } \\
\hline $0,00 \%-10 \%$ & Tidak Berkontribusi \\
$10,10 \%-20 \%$ & Kurang Berkontribusi \\
$20,10 \%-30 \%$ & Cukup Berkontribusi \\
$30,10 \%-40 \%$ & Berkontribusi \\
$40,10 \%-50 \%$ & Sangat Berkontribusi \\
\hline
\end{tabular}

Sumber: Depdagri, Kepmendagri No. 690.00.32 (Velayati at al, 2013)

Sistem Pengendalian Internal Menurut COSO. Committee of Sponsoring Organizations of The Treadway Commissions (COSO) yang dibentuk pada tahun 1985 bertujuan untuk mengidentifikasi faktor-faktor yang menyebabkan penggelapan laporan keuangan dan membuat rekomendasi untuk mengurangi kejadian tersebut. Menurut COSO framework, 
Internal control terdiri dari 5 komponen yang saling terkait, yaitu: lingkungan pengendalian, penaksiran risiko, aktivitas pengendalian, informasi dan komunikasi, dan pemantauan/monitoring.

Pajak. Pajak adalah iuran yang secara paksa harus dibayarkan oleh wajib pajak kepada negara sesuai dengan ketentuan yang berlaku serta tidak akan merasakan keuntungannya secara langsung dan hasilnya akan digunakan untuk merealisasikan pembangunan nasional. (Andriani dalam Waluyo, $2013: 2$ ).

Pajak Daerah. Menurut Priantara (2013 : 535) pajak daerah adalah kontribusi wajib yang terutang oleh orang pribadi atau badan yang mempunyai sifat memaksa dan berdasarkan undang-undang, orang pribadi atau badan tersebut tidak mendapatkan imbalan atau merasakan dampaknya secara langsung dan digunakan untuk kepentingan suatu daerah demi kesejahteraan rakyat.

Jenis dan Tarif Pajak Daerah. Menurut undang-undang tentang pajak daerah dan retribusi daerah tahun 2009, tarif yang ditetapkan atas pajak bahan bakar kendaraan bermotor paling tinggi adalah 10\%. Pajak bahan bakar kendaraan bermotor pada tahun 2011 mengalami perubahan, dimana pemerintah mengubah tarif menjadi 5\%. Perubahan atas tarif pajak bahan bakar kendaraan bermotor ditetapkan dalam Peraturan Presiden (Perpres) Nomor 36 Tahun 2011. Selain itu, perubahan tarif tersebut berdasarkan peraturan presiden hanya berlaku untuk bahan bakar kendaraan yang disubsidi.

Akuntansi. Menurut Dunia (2013 : 4) akuntansi merupakan suatu sistem informasi berupa laporan keuangan yang dibuat berdasarkan kegiatan transaksi keuangan dan akan digunakan sebagai laporan untuk pengambilan keputusan dalam sebuah kegiatan bisnis.

Pendapatan Asli Daerah. Menurut Arwati dan Hadiati (2013) menyatakan bahwa setiap penerimaan daerah yang berasal dari pajak, retribusi, hasil pengelolaan kekayaan, hasil usaha dan segala sektor penerimaan milik daerah merupakan pendapatan asli daerah.

\section{METODE PENELITIAN}

Jenis Penelitian. Jenis penelitian yang digunakan oleh penulis dalam melakukan penelitian ini adalah penelitian kualitatif deskriptif.

Tempat dan Waktu Penelitian. Penelitian dilakukan pada Badan Pengelola Pajak dan Retribusi Daerah Provinsi Sulawesi Utara, yang beralamat di Jalan 17 Agustus No. 67, Teling Atas, Wanea, Kota Manado, Sulawesi Utara 95117. Penelitian dimulai sejak bulan September 2018 - November 2018.

Jenis Data. Jenis data yang digunakan dalam penelitian ini adalah data kuantitatif dan data kualitatif yang berupa laporan penerimaan pajak bahan bakar kendaraan bermotor dan hasil wawancara.

Sumber Data. Sumber data yang digunakan oleh penulis dalam melakukan penelitian ini adalah data primer dan data sekunder. Dimana sumber data tersebut adalah hasil wawancara dan dokumentasi berupa laporan realisasi PAD dan PBBKB yang diperoleh dari sub bidang pajak yang mengurus tentang pajak bahan bakar kendaraan bermotor di kantor BPPRD Provinsi Sulawesi Utara.

\section{Metode Pengumpulan Data}

1. Wawancara. Wawancara yang dilakukan kepada sub bidang pajak bagian PBBKB kantor BPPRD Provinsi Sulawesi Utara. Adapun pertanyaan yang akan ditanyakan adalah sebagai berikut :

a. Apa saja faktor-faktor pertimbangan Pemerintah Provinsi Sulawesi Utara dalam menetapkan tarif pajak bahan bakar kendaraan bermotor?

b. Bagaimana prosedur perhitungan pajak bahan bakar kendaraan bermotor yang dilakukan oleh Pemerintah Sulawesi Utara? 
c. Apa saja faktor-faktor pertimbangan pemerintah dalam menetapkan target penerimaan pajak bahan bakar kendaraan bermotor setiap tahun? Apakah pemerintah memiliki metode perhitngan dalam menetapkan target tersebut?

d. Bagaimana tindakan pemerintah dalam melakukan audit sehubungan dengan hasil perhitungan, pemungutan dan pelaporan pajak atas penjualan bahan bakar kendaraan bermotor?

2. Dokumentasi. Dokumentasi dilakukan dengan mengumpulkan dokumen-dokumen yang diperlukan dalam proses penelitian pada Badan Pengelola Pajak dan Retribusi Daerah Provinsi Sulawesi Utara seperti:

a. Laporan realisasi pendapatan asli daerah Provinsi Sulawesi Utara tahun 2013-2017.

b. Laporan Realisasi penerimaan pajak Provinsi Sulawesi Utara tahun 2013-2017.

c. Laporan jumlah target pajak bahan bakar kendaraan bermotor Provinsi Sulawesi Utara tahun 2013-2017.

d. Laporan realisasi penerimaan pajak bahan bakar kendaraan bermotor Provinsi Sulawesi Utara tahun 2013-2017.

Metode dan Proses Analisis Data. Metode dan analisis data yang digunakan dalam penelitian ini adalah metode analisis deskriptif, yaitu menjelaskan efektivitas dari proses pemungutan pajak bahan bakar kendaraan bermotor berdasarkan sistem pengendalian internal yang telah diterapkan dan menghubungkan hasil penerimaan tersebut dengan pendapatan asli daerah sehingga dapat diketahui tingkat kontribusi pajak bahan bakar kendaraan bermotor terhadap pendapatan asli daerah Provinsi Sulawesi Utara.

\section{HASIL PENELITIAN DAN PEMBAHASAN}

\subsection{Hasil Penelitian}

Penerapan Sistem Pengendalian Internal Pada BPPRD Provinsi Sulawesi Utara.

Dalam melakukan kegiatan pemungutan pajak bahan bakar kendaraan bermotor, maka penyedia bahan bakar yang akan melakukan pemungutan dari konsumen yang diperoleh dari hasil penjualan. Setelah itu perusahaan yang telah terdaftar sebagai wajib pungut diwajibkan untuk menyetorkan hasil pemungutannya ke BPPRD. Penyetoran tersebut dilakukan dengan menggunakan SSPD paling lambat tanggal 20 bulan berikut dan apabila tanggal tersebut jatuh pada hari libur maka penyetoran dilakukan pada hari kerja berikutnya. Seluruh perusahaan penjual bahan bakar yang terdaftar merupakan wajib pungut tidak akan diberikan sanksi apapun dalam kegiatan pemungutan. Namun, apabila BPPRD melihat adanya kesenjangan dalam bukti penyetoran, maka BPPRD akan melakukan audit langsung ke perusahaan bersangkutan. Kecurangan sendiri belum pernah terjadi dalam kegiatan pelaporan hasil penerimaan penjualan bahan bakar, tetapi biasanya perbedaan hanya disebabkan oleh kesalahan perhitungan. Adapun hal-hal yang terjadi apabila tidak semua perusahaan melaporkan hasil penjualannya yaitu karena pendapatan perusahaan tersebut tidak terlalu besar. Sama dengan solusi yang dilakukan BPPRD dalam menyelesaikan masalah lainnya terkait kesenjangan dalam laporan hasil penjualan bahan bakar kendaraan bermotor, maka tindakan yang akan dilakukan oleh BPPRD adalah memeriksa kembali laporan penyetoran dari hasil penjualan dan melakukan audit atas laporan keuangan perusahaan dengan turun langsung ke lapangan. Kebijakan yang diterapkan untuk menghindari permasalahan, biasanya BPPRD melihat prospek dalam kegiatan penjualan masing-masing perusahaan, pasti ada perusahaan yang kegiatan penjualan bahan bakarnya aktif dan ada juga yang tidak. Setelah itu BPPRD juga akan melihat dari laporan penyetoran hasil penjualan pasti akan terdapat perbedaan yang signifikan dari jumlah setor untuk perusahaan yang kegiatan penjualannya aktif dengan yang kurang aktif. 
Target dan Realisasi Pajak Bahan Bakar Kendaraan Bermotor Provinsi Sulawesi Utara tahun 2013-2017. Berikut ini merupakan tabel target dan realisasi penerimaan Pajak Bahan Bakar Kendaraan Bermotor pada tahun 2013-2017.

Tabel 1. Target dan Realisasi PBBKB Provinsi Sulawesi Utara Tahun 2013-2017

Tahun Target PBBKB $\quad$ Realisasi PBBKB

\begin{tabular}{ccc} 
& $\begin{array}{c}\text { Target PBBKB } \\
\text { (Rp) }\end{array}$ & $\begin{array}{c}\text { Realisasi PBBKB } \\
\text { (Rp) }\end{array}$ \\
\hline 2013 & 143.240 .000 .000 & 156.602 .634 .526 \\
2014 & 183.336 .168 .000 & 196.938 .425 .823 \\
2015 & 220.123 .486 .640 & 203.967 .373 .500 \\
2016 & 181.123 .486 .640 & 187.366 .177 .880 \\
2017 & 200.816 .400 .000 & 219.745 .210 .591 \\
\hline
\end{tabular}

Sumber: Data Badan Pengelola Pajak dan Retribusi Daerah Pemerintah Provinsi Sulawesi Utara

Target dan Realisasi Pendapatan Asli Daerah (PAD) Provinsi Sulawesi Utara Tahun 2013-2017. Di bawah ini merupakan tabel target dan realisasi penerimaan Pendapatan Asli Daerah (PAD) pada tahun 2013-2017.

Tabel 2. Target dan Realisasi PAD Provinsi Sulawesi Utara Tahun 2013-2017

\begin{tabular}{ccr}
\hline Tahun & $\begin{array}{c}\text { Target PAD } \\
\text { (Rp) }\end{array}$ & $\begin{array}{c}\text { Realisasi PAD } \\
\text { (Rp) }\end{array}$ \\
\hline 2013 & 764.063 .464 .750 & 785.467 .967 .366 \\
2014 & 991.101 .010 .028 & 938.583 .020 .354 \\
2015 & 1.089 .288 .358 .000 & 1.012 .945 .961 .386 \\
2016 & 979.353 .945 .492 & 981.044 .550 .486 \\
2017 & 1.076 .342 .496 .000 & 981.235 .631 .829 \\
\hline
\end{tabular}

Sumber: Data Badan Pengelola Pajak dan Retribusi Daerah Pemerintah Provinsi Sulawesi Utara

\subsection{Pembahasan}

Efektivitas Penerimaan Pajak Bahan Bakar Kendaraan Bermotor Provinsi Sulawesi Utara Tahun 2013-2017. Di bawah ini merupakan tabel efektivitas penerimaan pajak bahan bakar kendaraan bermotor Provinsi Sulawesi Utara pada tahun 2013-2017.

Tabel 3. Efektivitas Penerimaan PBBKB Provinsi Sulawesi Utara Tahun 2013-2017

\begin{tabular}{cccrl}
\hline Tahun & $\begin{array}{c}\text { Target PBBKB } \\
(\mathbf{R p})\end{array}$ & $\begin{array}{c}\text { Realisasi PBBKB } \\
(\mathbf{R p})\end{array}$ & $\begin{array}{c}\text { Persentase } \\
(\boldsymbol{\%})\end{array}$ & Kriteria \\
\hline 2013 & 143.240 .000 .000 & 156.602 .634 .526 & $109,32 \%$ & Sangat Efektif \\
2014 & 183.336 .168 .000 & 196.938 .425 .823 & $107,41 \%$ & Sangat Efektif \\
2015 & 220.123 .486 .640 & 203.967 .373 .500 & $92,66 \%$ & Efektif \\
2016 & 181.123 .486 .640 & 187.366 .177 .880 & $103,44 \%$ & Sangat Efektif \\
2017 & 200.816 .400 .000 & 219.745 .210 .591 & $109,42 \%$ & Sangat Efektif \\
& Rata-rata & & $104,45 \%$ & Sangat Efektif \\
\hline
\end{tabular}

Sumber: Data Hasil Olahan 2018

Berdasarkan Tabel 3 di atas, dapat dilihat bahwa sistem pengendalian internal pada tahun 2013 dan 2014 berjalan dengan sangat baik sehingga pada realisasinya kriteria penerimaan pajak bahan bakar kendaraan bermotor melebihi target yang telah ditetapkan oleh BPPRD. Pada tahun 2015 penerapan sistem pengendalian internal kurang berjalan dengan baik sehingga pada penerimaannya pemerintah tidak mencapai target. Pada tahun 2016 dan 2017 sistem pengendalian internal telah berjalan dengan baik. Berdasarkan kriteria tersebut, 
efektivitas penerimaan pajak bahan bakar kendaraan bermotor tahun 2013-2017 memiliki kriteria sangat efektif dengan persentase perolehan sebesar $104.45 \%$.

Kontribusi Penerimaan Pajak Bahan Bakar Kendaraan Bermotor terhadap Pendapatan Asli Daerah Provinsi Sulawesi Utara tahun 2013-2017. Berikut ini merupakan tabel kontribusi penerimaan pajak bahan bakar kendaraan bermotor terhadap pendapatan asli daerah Provinsi Sulawesi Utara pada tahun 2013-2017.

Tabel 4. Kontribusi PBBKB terhadap PAD Provinsi Sulawesi Utara Tahun 2013-2017

\begin{tabular}{ccrrl}
\hline Tahun & $\begin{array}{c}\text { Realisasi PBBKB } \\
(\mathbf{R p})\end{array}$ & $\begin{array}{c}\text { Realisasi PAD } \\
(\mathbf{R p})\end{array}$ & $\begin{array}{c}\text { Persentase } \\
(\boldsymbol{\%})\end{array}$ & Kriteria \\
\hline 2013 & 156.602 .634 .526 & 785.467 .967 .366 & $19,93 \%$ & Kurang Berkontribusi \\
2014 & 196.938 .425 .823 & 938.583 .020 .354 & $20,98 \%$ & Cukup Berkontribusi \\
2015 & 203.967 .373 .500 & 1.012 .945 .961 .386 & $20,13 \%$ & Cukup Berkontribusi \\
2016 & 187.366 .177 .880 & 981.044 .550 .486 & $19,09 \%$ & Kurang Berkontribusi \\
2017 & 219.745 .210 .591 & 981.235 .631 .829 & $22,39 \%$ & Cukup Berkontribusi \\
& Rata-rata & & $20,50 \%$ & Cukup Berkontribusi \\
\hline
\end{tabular}

Sumber: Data Hasil Olahan 2018

Berdasarkan Tabel 4, persentase kontribusi pajak bahan bakar kendaraan bermotor Provinsi Sulawesi Utara dari tahun 2013 hingga 2017 selalu mengalami fluktuasi dalam kontribusinya untuk pendapatan asli daerah. Kriteria kontribusi pajak bahan bakar kendaraan bermotor terhadap pendapatan asli daerah pada tahun 2013 hanya sebesar 19,93\%, dimana pada tahun tersebut PBBKB dinyatakan kurang berkontribusi. Kenaikan terjadi pada tahun 2014 yaitu sebesar 20,98\% dan menyatakan bahwa PBBKB cukup berkontribusi. Pada tahun 2015 mengalami sedikit penurunan kriteria kontribusi yaitu menjadi 20,13\%. Pada tahun 2016 kontribusi PBBKB terhadap pendapatan asli daerah paling rendah, dimana PBBKB hanya menyumbang sekitar 19,09\% kepada pendapatan asli daerah. Pada tahun 2017 kontribusi PBBKB terhadap pendapatan asli daerah yaitu sebesar 22,39\%, dimana pada tahun tersebut merupakan kontribusi terbesar PBBKB terhadap PAD selama tahun 2013-2017. Tabel di atas juga menunjukkan bahwa pajak bahan bakar kendaraan bermotor cukup berkontribusi terhadap pendapatan asli daerah Provinsi Sulawesi Utara tahun 2013-2017 yaitu sebesar 20,50\%. Dari penjelasan kontribusi PBBKB tersebut dapat disimpulkan bahwa sistem pengendalian internal yang diterapkan oleh BPPRD telah berjalan dengan baik namun belum maksimal.

\section{KESIMPULAN DAN SARAN}

\subsection{Kesimpulan}

Berdasarkan hasil penelitian dan pembahasan pada bab sebelumnya, maka dapat diambil kesimpulan sebagai berikut :

1. Efektivitas pajak bahan bakar kendaraan bermotor di Provinsi Sulawesi Utara tahun 2013-2017 sangat fluktuatif. Penerapan sistem pengendalian internal dalam proses pemungutannya berjalan dengan baik, sehingga pajak bahan bakar kendaraan bermotor memiliki kriteria sangat efektif. Rata-rata efektivitas pajak bahan bakar kendaraan bermotor di Provinsi Sulawesi Utara selama 5 tahun memiliki kriteria sangat efektif dimana perolehan nilai rata-ratanya adalah sebesar $104,45 \%$.

2. Kontribusi pajak bahan bakar kendaraan bermotor terhadap pendapatan asli daerah di Provinsi Sulawesi Utara tahun 2013-2017 juga sangat fluktuatif. Rata-rata kontribusi PBBKB tahun 2013-2017 hanya sebesar 20,50\%, dimana jumlah tersebut menunjukkan bahwa PBBKB cukup berkontribusi untuk meningkatkan pendapatan asli daerah Provinsi Sulawesi Utara. Secara keseluruhan sitem pengendalian internal yang diterapkan sudah 
berjalan dengan baik, namun jika dibandingkan dengan sumber pendapatan daerah lainnya, maka pajak bahan bakar kendaraan bermotor sejauh ini belum terlalu memberikan kontribusi yang besar untuk meningkatkan pendapatan asli daerah.

3. Penerapan sistem pengendalian internal oleh Badan Pengelola Pajak dan Retribusi Daerah Provinsi Sulawesi Utara membuat proses perhitungan, pemungutan dan pelaporan PBBKB berjalan dengan baik. Hal tersebut berdampak pada realisasi penerimaan pajak bahan bakar kendaraan bermotor, dimana setiap tahun sangat efektif dan selalu mengalami peningkatan. Adapun kekurangan dalam proses pengendalian internal yaitu kurangnya sanksi yang diberikan kepada wajib pungut yang terlambat menyetorkan hasil penerimaannya, sehingga secara keseluruhan dapat berdampak pada jumlah kontribusi pajak bahan bakar kendaraan bermotor terhadap pendapatan asli daerah.

\subsection{Saran}

Berdasarkan penelitian yang telah dilakukan dan kesimpulan yang telah diperoleh, maka saran yang dapat penulis berikan antara lain :

1. Badan Pengelola Pajak dan Retribusi Daerah Provinsi Sulawesi Utara untuk tetap mempertahankan konsistensinya dalam melakukan pemungutan pajak bahan bakar kendaraan bermotor, sehingga efektivitas penerimaan PBBKB tetap bertahan ataupun semakin meningkat.

2. Badan Pengelola Pajak dan Retribusi Daerah Provinsi Sulawesi Utara harus mulai untuk menetapkan sanksi terhadap kecurangan dalam penyetoran hasil penerimaan penjualan bahan bakar yang suatu saat mungkin akan terjadi, sehingga hal tersebut dapat menjadi bentuk tindakan untuk meminimalisir kecurangan dikemudian hari.

\section{DAFTAR PUSTAKA}

Arwati., dan Hadiati. 2013. Pengaruh Pertumbuhan, Pendapatan Asli Daerah dan Alokasi Umum terhadap Pengalokasian Anggaran Belanja Modal pada Pemerintah Daerah Kabupaten/Kota di Provinsi Jawa Barat. Seminar Nasional Teknologi Informasi dan Terapan. 2013.

Bungkaes, H. R. 2013. Hubungan Efektivitas Pengelolaan Program Raskin dengan Peningkatan Kesejahteraan Masyarakat di Desa Mamahan Kecamatan Gemeh Kabupaten Kepulauan Talaud. Journal "Acta Diurna".

Committee of Sponsoring Organizations of the Treadway Commission (COSO). 2008. Pengendalian Internal \& Manajemen Risiko. Penerbit: Yayasan Pendidikan Internal Audit (YPIA). Jakarta.

Dunia, Firdaus A. 2013. Pengantar Akuntansi. Edisi 3. Penerbit: FE-UI. Jakarta.

Handoko, P Sri. 2013. Analisis Tingkat Efektivitas Pajak Daerah Sebagai Sumber Pendapatan Asli Daerah Kota Pontianak. Jurnal. Pontianak.

Supriadi, D. R. 2015. Kontribusi Pajak Hiburan dalam Meningkatkan Pendapatan Asli Daerah (PAD) di Kota Malang. Skripsi. FIAUniversitas Brawijaya. Malang.

Priantara, D. 2013. Perpajakan Indonesia. Edisi 2 Revisi. Penerbit Mitra Wacana Media. Jakarta.

Pura, Rahman. 2013. Pengantar Akuntansi I Pendekatan Siklus Akuntansi. Penerbit:Erlangga. Jakarta.

Velayati, M Rizkika, et al. 2013. Analisis Efektivitas dan Kontribusi Tindakan Penagihan Pajak Aktif dengan Surat Teguran dan Surat Paksa sebagai Upaya Pencairan Tunggakan Pajak. Studi pada Kantor Pelayanan Pajak Pratama Baru Tahun 2010-2012. Skripsi. Universitas Brawijaya. Malang.

Waluyo. 2013. Perpajakan Indonesia. Salemba Empat. Jakarta. 